\title{
El krausismo en la formación del movimiento reformista y liberal en Cuba (siglo XIX)*
}

\author{
por \\ Delphine Sappez \\ Universitat Jaume I \\ delphine_sappez@yahoo.fr
}

\begin{abstract}
El presente texto propone una revisión de las interpretaciones tendentes a minimizar la influencia del krausismo en Cuba, ampliando el campo habitual de la historia de las ideas cubana al análisis de las ideas jurídicas y políticas de la segunda mitad del siglo XIX. Este enfoque permite detectar un fuerte impacto del krausismo tanto en los reformistas de los años 1860 como en los autonomistas de los años 1880, y por ende en la cultura política regeneradora que más tarde se proyecta en la República.
\end{abstract}

Palabras clave: Cuba; siglo XIX; krausismo; reformismo; autonomismo.

Las élites intelectuales cubanas, a lo largo del siglo XIX, reivindicaron la creación de espacios de libertad, primero económica y luego política, con cada vez más insistencia. Esta búsqueda de libertad se acompañó de la elaboración de una identidad cubana. Para ello, se precisaban «héroes» fundadores para la patria que Cuba constituía dentro de la nación española. En efecto, el tardío acceso de Cuba al estado de nación independiente no impidió que, cuando la mayor parte de las naciones procuraban definir sus orígenes y sus límites, las élites cubanas intentaran también delinear su propia identidad, a veces en el marco de movimientos que podrían calificarse de protonacionales, pero no

\footnotetext{
* El presente texto se enmarca en el proyecto HAR2012-36481 del MINECO.
} 
necesariamente ${ }^{1}$. Según la coyuntura, los orígenes de esta identidad específicamente cubana se han situado de un lado o de otro del Atlántico.

De este modo, en el momento en que la mejor esperanza de reforma se vinculaba a la posibilidad de la anexión del territorio cubano a Estados Unidos apareció una corriente identitaria americanista, cuya expresión literaria fue el siboneísmo ${ }^{2}$. Sin embargo, en otras circunstancias, las élites cubanas recurrieron a las raíces españolas para definir, haciendo caso omiso del elevado porcentaje de población de origen africano en la isla, una cultura cubana occidental y blanca que pudiera otorgar al «pueblo cubano» un lugar entre los pueblos más «civilizados» del mundo. Cuando los siboneístas habían ensalzado la figura del indio Hatuey, quien había resistido a la invasión española, los liberales de la generación siguiente, para quienes la anexión a Estados Unidos ya no era una opción conveniente, exaltaban la figura de Cristóbal Colón ${ }^{3}$.

A partir de los años 1860 con el movimiento reformista, y más especialmente después de 1878 con el Partido Liberal Autonomista, los liberales cubanos buscaron el medio de conciliar libertad política y mantenimiento del vínculo colonial con España, así como identidad cubana y herencia española, optando por la autonomía colonial como programa político. Esta doctrina, que al fin y al cabo respondía sobre todo a la voluntad de asentar el Estado de Derecho en Cuba, es decir un sistema de gobierno basado en la representatividad que garantizara el ejercicio de las libertades individuales, se inspiraba en las teorías del Estado liberal y más particularmente en el modelo inglés en cuanto arquetipo estatal e imperial. Por otro lado, la fórmula autonomista adoptada por el Partido Liberal de la Isla de Cuba a partir de 1879 contenía un fuerte componente moral y una visión del mundo que nos parece apropiado vincular al krausismo, un fenómeno intelectual cuyo alcance en España ha sido ampliamente estudiado, pero que se ha negado casi por completo en el caso cubano.

En efecto, en contraposición con España y varios países de América Latina, Cuba no conoció un movimiento krausista visible. Por otra parte, el interés por algunas figuras autonomistas como Enrique José Varona o Rafael Montoro, cuyas inclinaciones filosóficas han sido identificadas en el primer caso con el positivismo y en el segundo con tendencias hegelianas, impidió,

\footnotetext{
1 Thiesse, 1999. Bertrand y Marin, 2001: 5-28. Sobre el caso cubano, Piqueras, 2012: 419-468.

${ }^{2}$ Este movimiento literario exaltaba el pasado primitivo de Cuba antes de la colonia española. Se inscribe a la vez en la tradición romántica y en la búsqueda de una literatura original. La figura más representativa de esta corriente, particularmente intensa en los años 1850, fue el poeta José Fornaris. Moreno Fraginals, 2002: 224. Opatrný, 2006: 45-58.

3 Ver, por ejemplo, Morales Morales, 1904: 1-28.
} 
a nuestro entender, que se buscaran otras influencias en el pensamiento de otros protagonistas no menos significativos para el movimiento como el secretario e ideólogo del Partido Autonomista, Antonio Govín. No obstante, si nos detenemos en las trayectorias individuales de éste y de muchos liberales cubanos de la segunda mitad del siglo XIX, el impacto del krausismo en su formación y en su pensamiento se hace evidente. Es más, si se entiende el autonomismo como un movimiento amplio que trasciende las fronteras del partido político para implantarse en todas las esferas de la sociedad -como las esferas cultural, profesional y moral, con la masonería- se puede observar la influencia del krausismo, más que la de cualquier otra filosofía.

La incapacidad de los autonomistas para crear un movimiento poderoso debe relacionarse, sin embargo, con la accidentada historia política de Cuba en aquel período y precisamente con la heterogeneidad del Partido Autonomista, en el que se agruparon intelectuales de diversas tendencias filosóficas y políticas por tener un objetivo común: el reconocimiento de la existencia de una identidad cubana diferenciada mediante el establecimiento de instituciones representativas. No puede considerarse, a pesar de la importancia que tuvo en la corriente autonomista, que el krausismo constituyera un factor de cohesión dentro del partido político que pretendía canalizarla. El fracaso final del autonomismo frente al movimiento independentista fue el resultado, en parte, de la incapacidad de sus dirigentes por crear una escuela duradera capaz de sobrevivir a la tormenta que supuso el cambio de estatus político de la isla a partir de 1899.

\section{PROBLEMAS HISTORIOGRÁFICOS}

La repercusión del krausismo en Cuba es un fenómeno en gran parte desconocido. La historia de las ideas elaborada al principio del siglo XX y que todavía sirve ampliamente de referencia, preocupada por enfatizar la obra de unos padres de la patria de origen cubano -y sobre todo no español-, ha concentrado su atención en la originalidad de sus pensadores y en su conexión con filósofos ajenos a la metrópoli. Esta tarea no resultó demasiado difícil, teniendo en cuenta que en el siglo XIX los pensadores españoles eran sobre todo los receptores y transmisores de filosofías extranjeras. No obstante, la filosofía de Krause está definitivamente asociada a España, por ser el único país europeo, con Bélgica, donde tuvo una repercusión significativa. De este modo, existe una tendencia general -acentuada desde el triunfo de la Revolución cubana en 1959- a minimizar la resonancia de las ideas de Karl Christian Friedrich Krause (1781-1832) en Cuba, y cuando es aceptada, es 
para afirmar que se produjo por completo al margen del vínculo con España ${ }^{4}$. La síntesis de O. Carlos Stoetzer sobre el krausismo en Hispanoamérica sigue las líneas generales de estas interpretaciones, llegando a la conclusión de que hubo un «eco» del krausismo en la isla, fuera directamente o a través de Ahrens, Roeder, Tiberghien o de los españoles, pero que no se produjo una verdadera penetración ${ }^{5}$.

Cabe reconocer que ninguno de los grandes pensadores cubanos del siglo XIX, como José de la Luz y Caballero, Enrique José Varona, José Martí o Rafael Montoro, fue «krausista», si se entiende el término como aplicable a quien adoptara, en su conjunto, el sistema de Krause. De hecho, si abordáramos el tema con esta estrechez de miras, tendríamos que dejar de considerar como tales a numerosos reconocidos krausistas españoles, que tampoco hicieron suya la filosofía de Krause, sino la adaptación que de ella hicieron otros pensadores como Heinrich Ahrens, Guillaume Tiberghien y sobre todo Julián Sanz del Río, quien optó por enfatizar los aspectos que él creía más adecuados a las condiciones particulares del pueblo español ${ }^{6}$. Dicho esto, tampoco podemos considerar a los pensadores cubanos antes mencionados como krausistas a la manera de los krausistas españoles. Solamente recibieron, directa o indirectamente, algunas influencias, y llegaron a coincidir en su pensamiento con ciertos aspectos del krausismo.

Según Stoetzer, el único verdadero krausista en Cuba habría sido el clérigo bayamés Tristán de Jesús Medina, quien se habría adherido a esta filosofía en el transcurso de sus viajes de estudios en Alemania y en Madrid, y llegó a defender la independencia para Cuba durante la Guerra de los Diez Años. Para Piñera, en cambio, la presencia del krausismo en Cuba se habría reducido a «un oscuro profesor de filosofía», Teófilo Martínez de Escobar, quien defendió en el curso de 1879 a 1880 en la Universidad de La Habana la adopción de la filosofía krausista. A pesar de que el autor lo presente como un hecho aislado, la fecha en que se produjo su discurso resulta especialmente relevante, como veremos después, ya que coincide con el año en que el Partido Liberal de la Isla de Cuba, creado en 1878, hizo de la autonomía su programa político ${ }^{7}$.

Se trata de una historia de los pensadores más que de las ideas que no tiene en cuenta un dato esencial: el krausismo, en su versión española, afectó más amplia y duraderamente a los juristas que a los filósofos, especialmente

\footnotetext{
${ }^{4}$ Vitier, 1970: 222-225 y 309. Piñera Llera, 1960: 77-79. Gómez Treto, 1989: 187-209. Torres-Cuevas, 2006: 94-95.

5 Stoetzer, 1998: 171-186.

${ }^{6}$ López Morillas, 1980: 71-72.

7 Piñera Llera, 1960: 77. Stoetzer, 1998: 175.
} 
a partir de los años 1850. Por consiguiente, a partir de la hipótesis según la cual la influencia de las ideas krausistas penetró en Cuba a través de España, sería lógico buscarla antes en los juristas cubanos de la segunda mitad del siglo XIX. Se nos presenta entonces un nuevo obstáculo: la ausencia de una historia jurídica cubana, o más exactamente de las ideas jurídicas, puesto que la historia del derecho cubano se confunde hasta el final del período colonial con la historia del derecho español.

Por otro lado, en cuanto a la historia política, la tradicional negación de la continuidad entre el movimiento reformista de los años 1860 y el autonomismo de la década de 1880 impide toda conexión filosófica entre ambos movimientos políticos ${ }^{8}$. Si eventualmente se reconoce la filiación krausista de un reformista como Antonio Bachiller y Morales -señalada por el propio José Martí-, a menudo se omite que los reformistas fueron quienes formaron en la Universidad a la mayor parte de los autonomistas de la generación posterior ${ }^{9}$. Una vez más, la historiografía nacional, en busca de precedentes y justificaciones, lleva parte de la responsabilidad. Los diferentes movimientos reformistas del siglo XIX se incluyen en la gesta nacional por haber tenido una incidencia positiva en la toma de conciencia de los habitantes de Cuba de formar una comunidad con unos intereses y una identidad comunes y específicos. Estos movimientos aparecen de este modo como preludios a las luchas por la independencia. Sin embargo, el autonomismo se ve descalificado por haberse opuesto a las insurrecciones independentistas de las que fue contemporáneo y haber intentado frenarlas ${ }^{10}$. Aunque los autonomistas reivindicaron la herencia reformista, siempre les fue negada. Uno de los argumentos más utilizados en este sentido, tanto ahora como entonces, es el hecho de que José Antonio Saco, principal figura del reformismo, reconocido como uno de los padres de la patria, hubiera rechazado el programa autonomista $-\mathrm{O}$ al menos ciertos aspectos del mismo- poco antes de fallecer ${ }^{11}$.

${ }^{8}$ Las expresiones más importantes del reformismo fueron el Círculo Reformista y el periódico El Siglo (1862-1868), dirigido por el conde de Pozos Dulces. Ver Cepero Bonilla, 1957. Lécuyer, 2001.

9 Gómez Treto, 1989: 194. Castro Bachiller, 1942: 121-130. Este último autor reproduce un artículo de José Martí, titulado "Antonio Bachiller y Morales", publicado en El Avisador hispano-americano, el 24 de enero de 1889.

${ }^{10}$ Sergio Aguirre califica los movimientos reformistas como «antirrevolucionarios», mientras que condena el movimiento autonomista del último cuarto del siglo XIX por «contrarrevolucionario» y «antinacional». Aguirre, 1990: 39-40.

${ }^{11}$ Los autonomistas defendieron su postura en dos artículos publicados en el periódico oficial del Partido Liberal, El Triunfo (La Habana), con los títulos "El cadáver de Saco" y "Saco fue autonomista" (19 y 29 de agosto de 1880). 
No puede negarse que el reformismo de los años 1860 respondía a una coyuntura y aspiraciones muy distintas a las de los autonomistas, a quienes una larga guerra de independencia (1868-1878) separaba de aquellos reformistas. En el transcurso se habían producido profundos cambios políticos y sociales, tanto en Cuba como en España ${ }^{12}$. También se ha demostrado que, en cierta medida, reformistas y autonomistas pertenecían a distintas categorías sociales: la principal novedad en el movimiento autonomista, que por primera vez pudo tomar la forma de un partido político, es el protagonismo en él de una clase media que en los períodos anteriores tenía un acceso considerablemente reducido a la política ${ }^{13}$. No obstante, el partido autonomista se inscribe en la continuidad directa del «partido reformista», que sin ser un partido político ya se designaba usualmente como tal, aunque sólo fuera por haber retomado los elementos de las reivindicaciones reformistas que pudieran adaptarse a su propia situación. Además, si nos detenemos en los «intelectuales orgánicos» de ambos movimientos, podemos observar que eran juristas en su mayor parte y que los intelectuales orgánicos del reformismo formaron a los del autonomismo $^{14}$.

\section{KRAUSISMO Y REFORMISTAS}

La idea según la cual, con motivo de su posición estratégica y de sus conexiones múltiples con el extranjero, Cuba ha estado en contacto con las ideas más novedosas, a menudo antes que España, es comúnmente aceptada. En este sentido, Torres-Cuevas plantea la eventualidad de que José de la Luz y Caballero, quien estuvo en Alemania entre 1828 y 1831, haya descubierto el krausismo alemán antes que los españoles. Sin embargo, el mismo autor subraya los límites de la influencia del krausismo en el pensamiento de Luz y Caballero, quien se convertiría en el maestro incontestado de los estudiantes de filosofía cubanos a lo largo del siglo XIX ${ }^{15}$. Si hubo verdaderos krausistas en Cuba, la lógica indica que la identificación con este pensamiento les llegó por otra vía. Por otro lado, a pesar del importante número de cubanos nacidos en familias acomodadas que recibieron su formación académica en Estados Unidos o en Francia, entre otros destinos, la mayor parte de los cubanos que llegaban a recibir una formación universitaria la recibían de España, fuera en

\footnotetext{
2 Piqueras, 2005: 97.

13 García Mora, 1999: 53-72.

${ }^{14}$ Sobre el concepto de intelectual orgánico, ver Gramsci, 1992: 388-396.

15 Torres-Cuevas, 2006: 94.
} 
la propia Habana o en la metrópoli. Si tenemos en cuenta que desde finales de los años 1850 el krausismo español reinaba tanto sobre la Universidad Central de Madrid como sobre el liberalismo progresista español, no podemos dejar de cuestionar las tesis según las cuales el krausismo tuvo un impacto mínimo en Cuba.

En La Habana, hacia 1850, un grupo de estudiantes brillantes solía recibir el apodo de «los siete Sabios de Grecia» ${ }^{16}$. Dos de ellos se convertirían en médicos, mientras que los otros cinco se harían abogados. Partiremos de este grupo de cinco hombres para explorar las modalidades de la recepción y difusión del krausismo en Cuba. Antonio González de Mendoza, Nicolás Azcárate, Francisco Fesser, José Ignacio Rodríguez y José Manuel Mestre influirían duraderamente, en efecto, en la generación siguiente, por su actividad política, cultural o profesional, en cuanto abogados y, sobre todo, como profesores en la Universidad de La Habana. También se encontrarían entre los principales portavoces del reformismo de los años 1860. Habían realizado la mayor parte de su formación universitaria en La Habana.

Cuadro 1. Trayectoria universitaria de los cinco «Sabios de Grecia»

\begin{tabular}{|l|c|c|c|c|}
\hline & $\begin{array}{c}\text { Licenciado } \\
\text { en Filosofía }\end{array}$ & $\begin{array}{c}\text { Doctor en } \\
\text { Filosofía }\end{array}$ & Licenciado en Derecho & $\begin{array}{c}\text { Doctor en } \\
\text { Derecho }\end{array}$ \\
\hline $\begin{array}{l}\text { Nicolás Azcárate } \\
\text { y Escobedo }\end{array}$ & 1850 & & $\begin{array}{c}1854 \text { (Universidad Central } \\
\text { de Madrid) }\end{array}$ & \\
\hline $\begin{array}{l}\text { Francisco Fesser } \\
\text { y Diago }\end{array}$ & & 1854 & 1856 \\
\hline $\begin{array}{l}\text { Antonio González } \\
\text { de Mendoza }\end{array}$ & 1851 & 1853 & 1853 & 1856 \\
\hline $\begin{array}{l}\text { José Manuel Mestre } \\
\text { y Domínguez }\end{array}$ & 1851 & 1853 & 1855 & 1863 \\
\hline $\begin{array}{l}\text { José Ignacio } \\
\text { Rodríguez } \\
\text { y Hernández }\end{array}$ & & & & \\
\hline
\end{tabular}

Fuente: elaboración propia a partir de las siguientes fuentes: Memoria acerca del estado de la enseñanza en la Universidad de La Habana en el curso de 1868 a 1869, 1870: 139-180. Azcárate Rosell, 1939: 16. Excepto la Licenciatura en Derecho de Nicolás Azcárate, todos los títulos mencionados fueron expedidos por la Universidad de La Habana.

\footnotetext{
${ }^{16}$ Azcárate Rosell, 1939: 18.
} 
El cuadro 1 nos permite poner de relieve la formación en Filosofía recibida previamente a los estudios de Derecho por tres de ellos. Antonio Bachiller y Morales, quien impartía las asignaturas de Filosofía del Derecho y Religión en la Universidad de La Habana desde 1842, parece haber sido un factor decisivo en la orientación del grupo y de la generación siguiente hacia el krausismo. En 1857 publicó la obra Elementos de Filosofía del Derecho o Curso de Derecho Natural, que serviría de obra de texto para sus alumnos hasta 1863 . En su discurso de apertura del curso universitario de 1861 a 1862, José Manuel Mestre, quien a su vez había llegado a hacerse cargo de la cátedra de Lógica, Física y Moral en la Universidad habanera, expresó con claridad su inclinación por la filosofía krausista y la influencia de Bachiller en ello:

Siempre recordaré con singular complacencia las lecciones del Señor Bachiller, lecciones merced a las cuales se despertó en los hijos de la Universidad el deseo de penetrar en las regiones de esa filosofía alemana, que el gigantesco genio de Krause parece haber coronado con el sistema de la armonía universal, y que tan digna es de ser detenida y profundamente estudiada, no siendo tampoco de echarse en olvido los esfuerzos con que desde hace muchos años el mismo Bachiller ha procurado hacernos familiares los más eminentes pensadores italianos contemporáneos ${ }^{17}$.

La filiación krausista de Antonio Bachiller y Morales fue rechazada por Rafael Montoro en el elogio que pronunció en 1889 con motivo de su muerte. Montoro se basaba en el hecho de que el profesor de Filosofía «prescindió casi por completo de la metafísica, fundamento esencialísimo y constante presuposición de todos los cursos de Krause. Aún tengo para mí que esta intrincada metafísica del pensador alemán, Bachiller no la conoció del todo, ni quiso conocerla a fondo jamás, por lo mucho que contradecía todos los hábitos de su inteligencia». Sin embargo, Montoro reconocía que Bachiller había adoptado la teoría del Derecho de Krause, que Ahrens se había encargado de difundir ${ }^{18}$. Ahora bien, como señalábamos más arriba, éste fue el caso de la mayor parte de los krausistas. Según Gonzalo Capellán, los krausistas españoles no habían sido tanto los seguidores de Krause como de los receptores y transmisores de las ideas del pensador alemán, como Ahrens, Tiberghien o el propio Sanz del Río:

Estaban plenamente convencidos de la verdad esencial de los fundamentos doctrinales de la filosofía krausiana tal y como Sanz del Río y otros los habían

17 Discurso de apertura del curso universitario de 1861 a 1862, titulado "De la filosofía en La Habana", pronunciado por José Manuel Mestre y citado en Rodríguez, 1909: 15.

18 Elogio de Antonio Bachiller y Morales por Rafael Montoro, 1889, citado por Vitier, 1970: 460. 
expuesto, y no consideraban necesario volver sobre ellos cuando abordaban cuestiones prácticas que, por otro lado, eran las que más les interesaban. Lo que acontecerá es que con el paso del tiempo y el declinar de la filosofía krausista serían sus postulados prácticos - como la teoría del Derecho- los que permanecerían con mayor fuerza en el contexto cultural de nuestro país, incluso mucho tiempo después de que la base metafísica sobre la que se sustentaban quedara completamente olvidada o desacreditada ${ }^{19}$.

Por consiguiente, podemos llegar a dos conclusiones: por un lado, la falta de identificación de Antonio Bachiller con la parte metafísica de la filosofía de Krause no es suficiente para negar su adhesión al krausismo; por otro lado, podemos afirmar que fue por la vía de las ideas jurídicas, al igual que en España, por donde el krausismo arraigó en Cuba. Dado el carácter simultáneo del desarrollo del krausismo español con la trayectoria docente de Antonio Bachiller, resulta difícil establecer el origen de las influencias que recibió. Era a la vez discípulo de José de la Luz y Caballero y dueño de una de las bibliotecas habaneras más completas de la época, en la cual no debían de faltar las publicaciones españolas ${ }^{20}$. En todo caso, la figura de Ahrens, a través de España o directamente, parece haber sido decisiva.

Al margen de las lecciones de Antonio Bachiller y Morales, debemos señalar un hecho que probablemente resultó tan determinante como aquéllas en la adopción del krausismo por los «Sabios de Grecia»: el paso del líder de este grupo de estudiantes, Nicolás Azcárate, por la Universidad Central de Madrid, en la misma época en que el krausismo empezaba a convertirse en escuela.

En cuanto volvió a Cuba, Azcárate puso en marcha la Revista de Jurisprudencia, cuyo primer número salió en 1856, bajo la dirección conjunta del propio Azcárate, José Manuel Mestre, José Ignacio Rodríguez y Francisco Fesser. En esta revista se publicaban las disposiciones oficiales, una crónica de los tribunales y artículos relativos a diferentes aspectos jurídicos. Entre ellos algunos trataban temas de actualidad en Cuba, como la propiedad de esclavos (coartación, hipotecas), los derechos de exportación, la situación monetaria, etc. Se concedía un espacio importante, paralelamente a los autores cubanos, a los juristas españoles de la época, krausistas en su mayoría. Tampoco quedaban desatendidas las doctrinas extranjeras, como puede observarse en varios artículos de Antonio Bachiller sobre la Filosofía del Derecho de autores franceses e italianos. Era habitual que aparecieran varios artículos expresando opiniones diferentes y dialogando entre sí sobre un mismo tema.

\footnotetext{
19 Capellán de Miguel, 2006: 37.

${ }^{20}$ Castro Bachiller, 1942: 7, 29 y 64. Morales Morales, 1949: 197-225.
} 
Se contaban entre los principales colaboradores de la revista el quinto «Sabio» jurista, Antonio González de Mendoza, además de Antonio Bachiller y Morales y José María Céspedes. Todos ellos eran miembros del grupo reformista y profesores en la Universidad de La Habana en la década de 1860. Céspedes era, sin duda alguna, uno de los más innovadores. A principios de 1867, propuso al Gobierno la creación de una cátedra de Oratoria Forense, ofreciéndose para impartirla gratuitamente. Antes de que se tomara una decisión al respecto, ya iniciada la Guerra de los Diez Años, abandonó su puesto para dirigirse a los Estados Unidos. Reformistas eran también varios colaboradores ocasionales de la revista como José Morales Lemus, Carlos Navarrete y Romay, el médico Luis de la Calle - uno de los siete «Sabios»- y Anselmo Suárez y Romero.

Otros se movían en torno a los espacios de sociabilidad de fuerte presencia reformista como Jesús Benigno Gálvez, socio del Liceo Literario y Artístico de La Habana y director a partir de 1866 de la revista El Liceo de La Habana. Jesús Benigno Gálvez también era el hermano de José María Gálvez, futuro presidente del Partido Liberal Autonomista. Máximo du Bouchet y Mendive y José Bruzón, quienes aportaron alguna contribución, serían más adelante miembros de la junta central del mismo partido. Otros miembros del claustro universitario menos comprometidos a nivel político llegaron a participar en la publicación, entre otros el rector de la Universidad de La Habana Francisco Durán y Cuervo, Antonio Prudencio López y José María de la Torre. La revista experimentó distintos cambios poco substanciales en su título y en su grupo director entre 1858 y 1866 . A lo largo de este último año de existencia puede observarse, aparte de la salida de Fesser y de Azcárate, quienes dejaron el puesto a su compañero de estudios Antonio González de Mendoza, la colaboración de otros dos futuros miembros de la directiva del Partido Liberal Autonomista, quienes también combatirían por la independencia en la Guerra de los Diez Años: José Eugenio Bernal y Antonio Zambrana ${ }^{21}$.

La Revista de Jurisprudencia desempeñó sin duda alguna un papel de formación en la generación de juristas que constituiría el Partido Liberal Autonomista, un papel tan importante como las horas dedicadas a estudiar en los bancos de la Universidad habanera. Otro poderoso impulso representaban las sesiones de los jueves y de los sábados del aula magna, en que brillaba el joven Rafael Morales y González -quien posteriormente sería un destacado independentista-, y a las que asistían futuros protagonistas del Partido Liberal Autonomista como Antonio Govín, José Eugenio Bernal, José Manuel Pascual, Leopoldo Cancio, Antonio Zambrana y Julián Gassie. Algunos de ellos

${ }^{21}$ Revista de Jurisprudencia, 1856-1866. Rodríguez, 1909: 41-45. 
pasarían primero por el campo insurrecto, siguiendo a Rafael Morales y a Ignacio Agramonte y Loynaz, otro estudiante de los que más destacaban en aquellas sesiones. Según el historiador Vidal Morales y Morales, quien era uno de los asistentes, en las discusiones de estas «juevinas» y «sabatinas» fue determinante la influencia de José Manuel Mestre ${ }^{22}$.

Mestre aparece una y otra vez, y parece haber sido el que dejó la impronta más fuerte en esta generación. Como señalamos, debía lo esencial de su pensamiento a Antonio Bachiller y Morales, pero también se había formado en contacto constante con Nicolás Azcárate: entre los distintos horizontes científicos que le ofreció Bachiller, eligió el krausista. A partir del momento en que la cátedra de Filosofía del Derecho le fue atribuida después de la reforma universitaria de 1863, la obra de referencia para la asignatura que sustituyó a los Elementos de la Filosofía del Derecho de Bachiller era una traducción al castelano de Ahrens. Es probable que entonces las obras de referencia fueran impuestas por las autoridades españolas, ya que en 1865 la lista de las obras fue remitida a la Universidad de La Habana por Real Orden ${ }^{23}$. Este hecho nos confirma en la idea de que en cuanto a la implantación del krausismo jurídico, hubo un movimiento innegable desde España hacia Cuba.

Los profesores reformistas sufrieron, al igual que los krausistas españoles, la persecución del moderantismo español en la década de 1860. Con la puesta en vigor del plan de estudios de 1863, los profesores de la antigua Facultad de Filosofía y Letras fueron desplazados, en su mayoría, hacia el Instituto de Segunda Enseñanza, del que fue nombrado director Antonio Bachiller y Morales. Es común la atribución al gobernador y capitán general Francisco Lersundi, quien llegó en 1866, del principio de la hostilidad del Gobierno español hacia la Universidad de La Habana y sus sospechas acerca de la «fidelidad» a España de su claustro ${ }^{24}$. Sin embargo, esta actitud ya se hizo sentir desde 1863, al menos por parte del Gobierno metropolitano, a pesar de la relativa benevolencia de los gobernadores Francisco Serrano (1859-1862) y Domingo Dulce (1862-1866) con los reformistas cubanos. El nombramiento de Lersundi no hizo más que adecuar el gobierno de la isla al de la península, controlado por los moderados desde 1863. Los nombramientos de Serrano y Dulce se debían a la Unión Liberal liderada por Leopoldo O'Donnell, que había estado en el poder desde 1858 hasta febrero de 1863. Aunque este partido de centro -el primero en la historia de España- mantuviera su hegemonía

\footnotetext{
22 Morales Morales, 1972: 48.

${ }^{23}$ Memoria acerca del estado de la enseñanza en la Universidad de La Habana en el curso de 1868 a 1869, 1870: 101 y 133. Rodríguez, 1909: 15.

${ }^{24}$ Armas, Torres-Cuevas y Cairo Ballester, 1984: 165-170.
} 
por tantos años gracias a una estrecha cooperación con el moderantismo, O’Donnell cayó, según Francisco Martínez Gallego, por disensiones en torno a las cuestiones coloniales. Volvería a presidir el Consejo de ministros en 1865 , por un año, pero por entonces la Unión Liberal ya habría perdido buena parte de su capacidad federativa. Nada más llegar al poder en 1863, los moderados pusieron en marcha la reforma universitaria para $\mathrm{Cuba}^{25}$.

Con el plan de 1863, el apartamiento de los reformistas de la Universidad, colocándolos en el Instituto, ya tenía visos de ser una medida si no represiva, al menos preventiva. Es evidente que los profesores de la antigua Facultad de Filosofía y Letras eran los más apropiados para dar las asignaturas del Instituto, que eran aproximadamente las mismas; no menos evidente es el hecho de que al suprimir su Facultad, se hacía necesario colocarlos en alguna parte. Pero también se les aislaba de la Universidad en sí, adquirían una categoría inferior: en el cuadro de profesores propuesto por el gobernador superior civil a finales de septiembre de 1863 para la nueva Facultad de Filosofía y Letras -que no se fundaría hasta 1871-, no aparecía ninguno de los reformistas más entusiastas ${ }^{26}$. Aunque creemos que no perdían influencia en el alumnado, puesto que la enseñanza segundaria era fundamental para la formación de su pensamiento, a nivel personal perdían prestigio. Es lo que deja intuir una instancia elevada por Jesús Benigno Gálvez, solicitando que se le cambiara la plaza que se le había atribuido en el Instituto por una cátedra en la Facultad de Derecho ${ }^{27}$.

La solicitud de Jesús Benigno Gálvez fue desestimada por el Real Consejo de Instrucción pública, con el pretexto de que no hubiera ganado ninguna oposición para una cátedra universitaria. Con lo cual, su título de doctor -en Derecho Civil y Canónico, obtenido en 1863- se consideraba como insuficiente. Sin embargo, poco antes de que el Consejo informara en este sentido, fueron transmitidas al Gobierno español disposiciones del rector de la Universidad de La Habana tomadas a finales de febrero de 1865 para remediar el grave problema que causaban las numerosas cátedras que aún quedaban vacantes en la Universidad. El rector había decidido dar a Bernardo del Riesgo, profesor de Complementos de Algebra, Geometría y Trigonometría en la Escuela Pro-

${ }^{25}$ Leopoldo O’Donnell había sido gobernador y capitán general de Cuba entre 1844 y 1848, siendo el responsable de la famosa represión de «La Escalera» en 1848. Era considerado por la opinión pública como «un auténtico campeón de la estabilidad en la relación entre la metrópoli y las colonias antillanas». Martínez Gallego, 2001: 12, 17, 116 y 229.

${ }_{26}$ Extracto de la carta núm. 2222 del gobernador superior civil al Ministerio de Ultramar, 28 de septiembre de 1863, Archivo Histórico Nacional, Madrid (AHN), Ultramar, leg. 272, exp. 1.

27 Extracto de la carta núm. 925 del gobernador superior civil al Ministerio de Ultramar, 26 de noviembre de 1864, AHN, Ultramar, leg. 272, exp. 1. 
fesional, una de estas cátedras. Había obtenido su título de doctor en Derecho Civil y Canónico menos de un año antes. Difícilmente le habría dado tiempo a ganar una oposición, sobre todo teniendo en cuenta que éstas no se habían convocado, y se estaban cubriendo las cátedras vacantes de manera provisional, por nombramiento. Si Bernardo del Riesgo tenía alguna ventaja con respecto a Jesús Benigno Gálvez, era la de la edad, y probablemente la experiencia, puesto que se había graduado de licenciado en 1850, mientras que Gálvez había obtenido el mismo título en 1862. Pero ciertamente no era el hecho de haber ganado una oposición para una cátedra universitaria. El Gobierno español aprobó, a pesar de ello, el nombramiento provisional de Riesgo, aunque denegó la solicitud de propiedad de la cátedra que había sometido ${ }^{28}$.

José Manuel Mestre, catedrático propietario de la antigua Facultad de Filosofía y Letras, perdía su cátedra en el nuevo plan, sin que fuera sustituida por otra en el Instituto. Se quedaba en la Universidad, pero para desempeñar una cátedra correspondiente al período de doctorado de la Facultad de Jurisprudencia: la de Filosofía del Derecho, Derecho Internacional y Legislación Comparada. Por muy interesante que pudiera resultar la explicación de tal asignatura, eran menos numerosos los estudiantes que se matriculaban en el doctorado, puesto que era suficiente el título de licenciado para ejercer la abogacía. A principios del curso de 1868 a 1869, por ejemplo, no eran más de 20 los alumnos matriculados en las asignaturas del curso correspondiente al doctorado, mientras que en asignaturas de otros cursos, llegaban hasta $51^{29}$. Quizás por esta razón, Mestre solicitó en noviembre de 1864 que se le permitiera seguir dando las clases que había dado en la Facultad suprimida, trasladadas al Instituto. Obtuvo el apoyo del rector Durán y Cuervo, quien reconocía sus méritos como profesor y señalaba además el beneficio que sacaría la Universidad al realizar la economía del pago de otro profesor para dichas clases ${ }^{30}$.

El caso más sorprendente es el de Antonio González de Mendoza, miembro del Consejo de Administración -órgano consultivo del Gobierno general-, miembro destacado del Círculo Reformista a partir de 1866, socio fundador del Círculo de La Habana -sociedad de recreo- y socio del Liceo de La Habana. Después de haber sido aprobada la permuta de su cátedra con la de José

${ }^{28}$ Extracto de la carta núm. 1077 del gobernador superior civil al Ministerio de Ultramar, 27 de febrero de 1865; Nota del negociado de Fomento, 4 de julio de 1865, AHN, Ultramar, leg. 272, exp. 1.

${ }^{29}$ Memoria acerca del estado de la enseñanza en la Universidad de La Habana en el curso de 1868 a 1869, 1870: 72.

${ }^{30}$ Extracto de la carta núm. 924 del gobernador superior civil al Ministerio de Ultramar, 30 de noviembre de 1864, AHN, Ultramar, leg. 272, exp. 1. 
María Céspedes en 1865, quedándose con la de Derecho Penal y Mercantil, esta cátedra fue dividida en dos: Derecho Mercantil a cargo del propio Mendoza, y Derecho Penal, que se atribuyó a ¡Bernardo del Riesgo! Al informar sobre el asunto en mayo de 1865, el Consejo de Instrucción pública entendió que no había lugar a dividir la cátedra, y que correspondía su desempeño a Riesgo, proponiendo que se diera a González de Mendoza una de las cátedras vacantes; lo que fue dispuesto por real orden de 12 de julio de $1865^{31}$.

Al gobernador superior civil Domingo Dulce le pareció injusta tal medida, y dispuso la reunificación de la cátedra de Derecho Penal y Mercantil, pero atribuyéndola a Antonio González de Mendoza, mientras que Bernardo del Riesgo era nombrado para desempeñar la de Legislación Comparada ${ }^{32}$. Bernardo del Riesgo se dirigió entonces directamente al Gobierno español, quejándose contra el gobernador. Pedía el cumplimiento de la medida de 12 de julio, arguyendo que éste no tenía capacidad para «oponerse a los mandatos soberanos, ni mucho menos pretextar equivocación en asuntos de personal, cuando la ley franquea al que se cree perjudicado, los medios de acudir a S.M. para alcanzar la reparación». En diciembre del mismo año se le dio la razón. En 1866, González de Mendoza y José Manuel Mestre, en signo de protesta, se retiraron de la Universidad ${ }^{33}$.

Por otra parte, el rector de la Universidad José Valdés Fauli también fue sustituido en julio de 1864 por Francisco Durán y Cuervo, a pesar de que éste solo fuera el segundo nombre propuesto por el gobernador superior civil para desempeñar el cargo, mientras que Valdés Fauli era el primero de la lista. Era un miembro activo del grupo reformista, como indica el hecho de que, además de formar parte de la junta directiva del periódico El Siglo, en 1866 pronunciara un discurso en honor al periodista liberal español Eduardo Asquerino en un banquete que le ofreció el Círculo Reformista en «Las Tullerías». En este banquete también hablaron José Manuel Mestre, José Ignacio Rodríguez y la plana mayor de esta asociación política ${ }^{34}$. Francisco Durán y Cuervo, en cambio, sería miembro del Centro Hispano-Ultramarino de Madrid en 1872. Esta institución fue fundada a finales de 1871 como eco al Casino Español

31 Informe del Real Consejo de Instrucción pública, 20 de mayo de 1865, AHN, Ultramar, leg. 272, exp. 1. En este informe aparece que el rector no había dado ninguna razón para justificar la división de la cátedra.

${ }^{32}$ Extracto de la carta núm. 1388 del gobernador superior civil al Ministerio de Ultramar, 28 de agosto de 1865, AHN, Ultramar, leg. 272, exp. 1.

${ }^{33}$ Extracto de la instancia de Bernardo del Riesgo y Moris, 14 de septiembre de 1865, y Nota del negociado de Fomento, 5 de diciembre de 1865, AHN, Ultramar, leg. 272, exp. 1. Rodríguez, 1909: 68.

${ }^{34}$ Azcárate Rosell, 1939: 75. 
de La Habana (1870). Aunque no fuera tan radical en su inmovilismo colonial, a lo largo del año 1872 se crearon centros hispano-ultramarinos en toda la península, y en enero de 1873 se reunieron en una «Liga defensora de la integridad nacional», organización declaradamente política cuyo objetivo era enfrentarse al Gobierno democrático establecido, y no sólo con respecto al tema de las reformas coloniales ${ }^{35}$. No obstante, Durán y Cuervo parece haber actuado de consuno con Dulce en el asunto que opuso Antonio González de Mendoza a Bernardo del Riesgo, y además en 1865 nombró a varios profesores cercanos a los reformistas como Jesús Benigno Gálvez y Carlos Navarrete y Romay para desempeñar cátedras vacantes de la Facultad de Derecho ${ }^{36}$.

En cambio, nos llama la atención que quien desempeñara la cátedra de Economía Política, ciencia reivindicada como elemento de progreso por los juristas liberales, fuera el principal redactor del periódico ultramontano $\mathrm{La}$ Verdad católica, José Ramírez Ovando, y eso desde $1863^{37}$. Si no podía saltarse el programa impuesto por la Universidad peninsular, el Gobierno se aseguraba con este nombramiento de que no prosperaran demasiado rápido las doctrinas de esta ciencia alabada en julio de 1868 por los redactores de El País, periódico que pretendía proseguir la obra de publicidad de El Siglo, desaparecido a raíz de la fuerte censura de la que fue objeto. Consideraban que la Economía Política tendía a la felicidad de la humanidad:

Ha sabido fijar las relaciones entre gobernantes y gobernados, y los que antes medrar podían amparados por la oscuridad de las tinieblas, hoy, merced a los adelantos de la ciencia tienen que soltar el disfraz que encubriera tan benéficos propósitos o soportar el sonrojo de que se lo arranquen ${ }^{38}$.

No resulta sorprendente que las autoridades españolas manejaran así a su antojo la distribución de cátedras, en un período en que en la península, la publicación de un artículo de prensa podía llevar a un catedrático de la Universidad madrileña a perder su puesto, como sucedió con Emilio Castelar en 1865, siendo el detonante de la llamada noche de San Daniel, en que la protesta

35 Guerrero Cano, 2008: 113-125.

${ }^{36}$ Extracto de la carta núm. 1238 del gobernador superior civil al Ministerio de Ultramar, 26 de mayo de 1865, AHN, Ultramar, leg. 272, exp. 1.

37 Memoria acerca del estado de la enseñanza en la Universidad de La Habana en el curso de 1868 a 1869, 1870: 96-97 y 132. Ramírez Ovando también había sustituido a Jesús Benigno Gálvez en la asignatura de Historia eclesiástica, concilios y colecciones canónicas.

${ }_{38}$ Artículo remitido al Ministerio de Ultramar por el gobernador superior civil (El País, La Habana, 11 de julio de 1868, totalmente suprimido), 15 de julio de 1868, AHN, Ultramar, leg. 4716, caja 1, exp. 2. 
estudiantil contra esta disposición abrió el paso a un motín republicano ${ }^{39}$. Las revoluciones de 1868, tanto en Cuba como en España, recibieron el apoyo de los intelectuales krausistas, a pesar de que la filosofía de Krause tendiera a manifestarse en posturas políticas reformistas y evolucionistas. Gumersindo de Azcárate, uno de los principales difusores del krausismo jurídico español, llegaría a justificar la utilización excepcional de métodos revolucionarios para asegurar una base sólida para iniciar un proceso de reforma progresiva de la tradición existente hacia la libertad:

Allí donde no impera el self-government, entendido como el gobierno de la sociedad por sí misma, que a su vez precisa el respeto a las libertades, de imprenta, de reunión y asociación, de conciencia, de enseñanza, de comercio..., la revolución se hace legítima. Pero simultáneamente plantea que una vez restablecidas esas condiciones básicas para el libre desarrollo de las sociedades hay que volver al orden y olvidarse de la revolución, que nunca puede ser considerada como un fin en sí mismo, sino exclusivamente como un medio al que recurrir en las circunstancias apuntadas $^{40}$.

La mayoría de los reformistas cubanos -exceptuando a Nicolás Azcárate- adoptaron una actitud similar ante la insurrección declarada el 10 de octubre de 1868 en el oriente de la isla. En los meses siguientes, empezaron por reivindicar la implantación de un régimen de libertad de acuerdo con los logros de la revolución española: en enero de 1869 plantearon la autonomía como mejor solución, retomando lo esencial del proyecto político redactado por José Morales Lemus y presentado por los comisionados reformistas a la Junta de Información convocada en 1866 por el Ministerio de Ultramar, en la que habían sido desatendidas sus reivindicaciones. Ante el fracaso de esta opción evolucionista, marcharon al exilio, dejando de obstaculizar y apoyando francamente, en muchos casos, el levantamiento cubano que aparecía entonces como el único medio de alcanzar el self-government ${ }^{41}$.

39 Piqueras y Sebastià, 1991: 84-86.

40 Capellán de Miguel, 2006: 194.

${ }^{41}$ Antonio Bachiller y Morales, Reuniones en casa del Marqués de Campo Florido (copia manuscrita), 1869, Biblioteca Nacional José Martí, La Habana (BNJM), 082 Morales t. XXIX (núm. 1), doc. 31. Hoja impresa titulada: Reuniones celebradas en casa del marqués de Campo Florido los días 13 y 18 de enero de 1869. Contiene extracto de informe que los comisionados Juan Poey, Conde de Pozos Dulces, Antonio Bachiller y Morales y otros, elevan a la Junta relativo a la conveniencia del sistema autonómico para Cuba, 1 de febrero de 1869, Archivo Nacional de Cuba, La Habana (ANC), Donativos, caja 448-A, exp. 14. Los demás miembros de la comisión eran Domingo Sterling, Juan Poci y el conde de Pozos Dulces. Sobre la Junta de Información, ver Alvarado, 2001: 211-217. 
Ahora bien, la revolución cubana de 1868 no fue en absoluto gloriosa. Desencadenó diez años de enfrentamientos sangrientos y no desembocó en el triunfo de los independentistas. Para entonces la revolución española también había fracasado, pero los krausistas españoles habían aprovechado los años del Sexenio Democrático para asentar un poderoso movimiento intelectual que les permitió enfrentarse a los ataques que la Restauración supuso para las libertades que defendían, creando la Institución Libre de Enseñanza para proteger su libertad de cátedra. En 1878, los antiguos reformistas cubanos se encontraban dispersados y desilusionados, y cuando volvieron a Cuba se mantuvieron al margen del escenario político.

Sin embargo, la historia que unía krausismo y liberalismo cubano no había acabado: los reformistas cubanos no habían conseguido crear una escuela intelectual que tomara las riendas del ámbito universitario, ya que su obra formadora había quedado truncada por la guerra y sus discípulos se habían visto privados del acceso al camino hacia las cátedras universitarias con la supresión de los estudios de doctorado en 1871. No obstante, estos discípulos habían encontrado otros espacios en los que pudieran crear y difundir pensamiento, como la masonería, considerada por Krause como la institución suprema destinada a realizar los más altos fines del hombre: la Alianza de la Humanidad ${ }^{42}$. Esta nueva generación, desarrollando el pensamiento de sus maestros, adaptaría el pensamiento krausista a su propio contexto sociopolítico, sacando conclusiones diferentes a las de la mayoría de los krausistas españoles, especialmente en cuanto a la concepción del vínculo colonial entre Cuba y España.

EL AUTONOMISMO O LA ADAPTACIÓN DEL KRAUSISMO A UN CONTEXTO COLONIAL

A raíz de la Guerra de los Diez Años, terminada en febrero de 1878 con una promesa de reforma política por parte de las autoridades españolas, se tomaron medidas para favorecer el desarrollo de una esfera pública en cuyo seno pudieran expresarse los intereses cubanos. El primer partido político cubano, creado en 1878 con el nombre de Partido Liberal de la Isla de Cuba, era el resultado de la iniciativa tomada por la nueva generación de juristas formados

42 Para Krause, cada uno de los fines de la humanidad correspondía a una «alianza» destinada a favorecer su realización. En un nivel inferior a la Alianza de la Humanidad estaban las Alianzas para el Derecho (Estado) y la religión (la Iglesia, entendida en el sentido más amplio posible); en un tercer nivel situaba las Alianzas para la Virtud, la Belleza, la Educación, el Arte y la Ciencia. Ureña, 1991: 183-184. 
en los años 1860 y $1870^{43}$. En efecto, se puede comprobar una proporción de 56,5 a $71,1 \%$ de abogados en la junta central del Partido Liberal entre 1878 y 1895 , con una clara tendencia ascendente ${ }^{44}$. Muchos de ellos eran masones, en una época en la cual, dada la situación política hasta 1878 , la masonería había constituido el único espacio de sociabilidad accesible. Por lo tanto, las logias masónicas desempeñaron un papel fundamental en la definición de una identidad y la proyección de una sociedad cubanas, más intensamente a partir de $1876^{45}$. También encontramos a los futuros autonomistas en 1877 entre los fundadores de la Sociedad Antropológica de la Isla de Cuba y en el comité de redacción de la Revista de Cuba, fundada por José Antonio Cortina. En las páginas de esta publicación se puede observar la influencia del krausismo hasta en ámbitos como la crítica literaria, así como la admiración por Inglaterra, otro aspecto característico del krausismo español. Sin embargo, es de notar una diferencia significativa: cuando los krausistas españoles alababan el régimen parlamentario de la nación británica, los autonomistas cubanos pintaban las ventajas de su sistema colonial ${ }^{46}$.

Con el apoyo de algunas figuras procedentes del campo independentista y de una base de pequeños y medianos propietarios, estos juristas quienes habían adoptado el nombre de liberales -aunque se declararon autonomistas desde el año 1879, sólo fue a partir de 1881 cuando se empezó a añadir progresivamente a la denominación de Partido Liberal el título de Autonomistarepresentaban la voluntad de la clase media de origen esencialmente insular de tomar en sus manos el destino, al menos económico, del país ${ }^{47}$. También se observa en ellos un deseo arraigado de poner en marcha los mecanismos del Estado de Derecho, es decir las garantías jurídicas necesarias no sólo a la libre iniciativa económica, sino también al ejercicio de derechos y libertades «fundamentales» destinados a favorecer la participación de los habitantes de

43 Sobre el Partido Liberal de la Isla de Cuba o Partido Liberal Autonomista, ver Bizcarrondo y Elorza, 2001. García Mora, 2001: 715-748, entre otros artículos del mismo autor.

${ }^{44}$ Realizamos este cálculo a partir de la lista de miembros de la junta central del Partido Liberal publicada por Bizcarrondo y Elorza, 2001: 433-436, y de las listas de abogados publicadas por el Colegio de Abogados de La Habana en 1880, 1881, 1885, 1887, 1888, 1889,1894 y 1897.

45 Sobre este tema, ver Soucy, 2006. Torres-Cuevas, 2005.

46 "Prospecto", Revista de Cuba, 4 (La Habana, 1878): 7-8. Unos ejemplos de crítica literaria influida por el krausismo en Govín, Antonio, "Estudios jurídicos ", Revista de Cuba, 1 (La Habana, 1877): 49-56 y, del mismo autor, "Crítica literaria", Revista de Cuba, 3 (La Habana, 1878): 403-414. Sobre la Sociedad Antropológica, ver Naranjo y García González, 1996. García Mora y Naranjo, 1997. Boletín de la Sociedad Antropológica de la Isla de Cuba, vol. I, La Habana, 1879.

47 García Mora, 1999: 53-72. 
Cuba en la vida política de su patria -Cuba-y de la «Madre patria»-España-, o, en otros términos, su acceso a la condición de ciudadanos. Por otra parte, estas libertades suponían asimismo la instauración de condiciones propicias al desarrollo de una ciencia, una literatura, un arte propios, en fin, de una cultura específicamente cubanas.

Es a uno de estos juristas formados en el ambiente krausista de la Universidad de La Habana de los años 1860, Antonio Govín y Torres, a quien incumbió la tarea de elaborar la doctrina del Partido Liberal a partir de 1879, cuando asumió la secretaría del mismo. Antonio Govín, cuyo nombre masónico era Krause, se había mostrado favorable a la opción autonomista desde 1878, pero no fue hasta el año siguiente cuando la mayor parte del grupo dirigente aceptó hacer de ella su bandera. El contenido de la biblioteca de Antonio Govín no deja ninguna duda acerca de la mediación española en su interés por el pensamiento de Krause: de las 17 obras que pueden relacionarse con el krausismo, 13 corresponden a autores españoles -en particular Adolfo Posada y Gumersindo de Azcárate- y solamente cuatro a los krausistas alemán y belga Ahrens y Tiberghien. De estas últimas tres son traducciones al español. En cuanto a Krause, resulta por completo ausente de esta biblioteca que sin embargo no puede tacharse de pobre y en la cual el castellano dista de ser el idioma más expandido ${ }^{48}$.

Desde 1879, Antonio Govín trabajó en la formulación de lo que sería la organización ideal de la autonomía colonial, basándose en el principio de selfgovernment tan utilizado por los krausistas, o descentralización administrativa, o bien, según lo entendía Gumersindo de Azcárate, soberanía nacional ${ }^{49}$. Teóricamente, la soberanía le correspondía a la nación española, y la doctrina propuesta por Antonio Govín no dejaba de recordarlo. Sin embargo, la autonomía proyectada, al llevar la descentralización hasta la creación de un nivel insular, superior al municipio y a la provincia -Cuba se componía de seis provincias en 1878-, con las correspondientes instituciones representativas, permitiría dotar a los cubanos de una unidad, mientras que la centralización de la administración en manos del gobernador general radicado en La Habana sólo le daba una unidad ficticia a la isla. Por otro lado, la autonomía de Cuba remarcaría su diversidad con respecto a los otros territorios españoles que no poseían este nivel de descentralización, aunque lo reivindicaran en algunos casos como el de Cataluña. Por tanto, la autonomía le concedería a Cuba un

48 Las obras en castellano sólo representan un 20,5\% de un total de 1.934 inventariadas en un catálogo realizado en 1924, frente a un 36,8\% de obras en francés y un 35,5\% en inglés. Catálogo de la biblioteca del Dr. Antonio Govín y Torres, 1924.

49 Azcárate, 1877; 1931: 18. 
marco institucional que se acercaría más al de una «nación propia», como reivindicaba Antonio Govín en los inicios de su carrera periodística, que al de la colonia concebida como apéndice territorial de una nación imperial:

Jamás debe olvidarse que entre la colonia y la metrópoli no caben sino vínculos puramente morales, nacidos de la historia, de la lengua, de la religión, de cierta mancomunidad en los intereses; y que respecto a los lazos fraternales que nacen de la continuidad del territorio, de la unidad del suelo, no pueden existir; porque a ello se opone la naturaleza. De la diversidad en el orden físico, procede la diversidad en las necesidades e intereses, y por ende la diversidad en el gobierno y la administración. La colonia, por las razones apuntadas, tiene prescrita de antemano una esfera de nación propia, aunque subordinada ${ }^{50}$.

Es precisamente en este punto en el que la teoría del Partido Autonomista se aleja del krausismo español. Aunque los políticos krausistas representaban en España el sector del liberalismo más dispuesto a aceptar la autonomía para Cuba, mantuvieron cierta resistencia a su puesta en práctica en todos los ámbitos de la vida cubana, teñida del temor a que España perdiera la colonia en que se fundamentaba buena parte de su riqueza, aceptando el argumento común a todas las tendencias políticas según el cual se corría el riesgo de que la autonomía condujera a la independencia. Esta resistencia se observa claramente en el Partido Republicano Centralista de Nicolás Salmerón, fundado en 1891, que no llegó a apoyar francamente la autonomía hasta la Guerra de Independencia iniciada en 1895. También se hace patente entre los masones españoles quienes, al margen de sus ideas políticas, se negaban a reconocer la existencia de una masonería independiente en Cuba, aunque ésta, unificada desde 1881 bajo la dirección de Antonio Govín, superara en muchos aspectos a su(s) equivalente(s) española(s) -la masonería española se encontraba entonces dividida en varias obediencias-, fuera en el plano organizativo, de las relaciones internacionales o de las prácticas específicamente masónicas ${ }^{51}$.

El propio Rafael María de Labra, principal y a veces único defensor de la autonomía colonial en el Parlamento, criticaba duramente las estrategias de la junta central del Partido Liberal Autonomista, lamentando que ésta no le dejara una mayor libertad de acción y recordando constantemente a sus

${ }^{50}$ [Govín, Antonio], "Los partidos políticos en Cuba”, I, El Triunfo (La Habana, 26 de julio de 1878). Los principales documentos en que Antonio Govín expuso la doctrina del Partido Liberal Autonomista están recogidos en "La Junta Magna del Partido Liberal de Cuba, celebrada el día $1^{\circ}$ de abril de 1882”, El Triunfo, La Habana, 1882: 37-67. Sobre esta figura, ver Sappez, 2016.

51 Sappez, 2010a: 559-572. 
miembros su inexperiencia y su ignorancia en cuanto a los mecanismos de la política metropolitana, remarcando al mismo tiempo su propia superioridad sobre ellos en este ámbito ${ }^{52}$. Nuestra hipótesis es que esta resistencia era en parte fruto de la visión eurocentrista del krausismo.

Esta concepción del mundo se fundamentaba en la idea de Krause según la cual la humanidad aún no habría llegado a la edad adulta, encontrándose en un proceso de evolución progresiva hacia lo que llamaba «el ideal de la humanidad». Las consecuencias de este punto de vista a nivel político se manifestaban en la adopción de posturas reformistas, pero siempre respetuosas de las leyes existentes: la evolución hacia el ideal de la humanidad siempre debería llevarse a cabo de acuerdo con las circunstancias históricas de cada momento. Otra consecuencia directa era la idea de que incumbía a los pueblos más maduros, o más «civilizados», guiar a los pueblos menos educados hacia el ideal de la alianza universal. Naturalmente, tanto para Krause como para los krausistas, era Europa la que ocupaba esta posición privilegiada ${ }^{53}$. Precisamente, el argumento utilizado reiteradamente por los autonomistas para justificar sus reivindicaciones descansaba en la idea de que la sociedad cubana había alcanzado la compleja organización propia de la madurez de los pueblos y merecía, por consiguiente, el acceso a la soberanía mediante el ejercicio de la ciudadanía ${ }^{54}$.

He aquí los postulados del conflicto entre aquellos liberales cubanos y españoles que habían elaborado su pensamiento en el mismo crisol de la filosofía krausista. Por un lado estaban los liberales krausistas españoles quienes, recordémoslo, habían sido los protagonistas del Sexenio Democrático (18681874). Habían declarado entonces su voluntad de aplicar a Cuba y Puerto Rico las nuevas garantías proporcionadas por la Constitución de 1869, aunque no fueron llevadas a Cuba con motivo de las presiones ejercidas por los negreros cubanos en el Gobierno ${ }^{55}$. Desde su punto de vista, el apoyo a la causa autonomista se vinculaba al deber de España, como pueblo más maduro, de transmitir y compartir su civilización -medida en términos de libertad-a sus colonias; no era sino la consecuencia de una profunda convicción democrática. Para los autonomistas cubanos, se había producido un proceso inverso: los principios liberales y democráticos eran los corolarios de su voluntad de

52 Sappez, 2010b: 209-218.

53 Capellán de Miguel, 2006: 72-73.

${ }^{54}$ Esta idea es recurrente en los discursos de Antonio Govín. Entre otros textos, ver [Govín], 1880: 6-8. "El concepto de la colonización, conferencia dada por el Dr. Antonio Govín y Torres en el Círculo Autonomista en la noche del día 14 de noviembre de 1887”, Tarafa y Govín, 1955: 303-321.

55 Piqueras, 1992: 259-390. 
libertad y no sólo de participación política, sino también de soberanía, una voluntad originada en la certidumbre de haber adquirido las capacidades necesarias para poder ejercerla ${ }^{56}$.

Calificaremos la primera tendencia de «españolista», aunque sin identificarla con el españolismo a ultranza profesado por los miembros del Partido de Unión Constitucional fundado en La Habana en 1878, unos días después de la aparición del Partido Liberal, como portavoz de los grandes intereses azucareros y comerciales, defensor del estatu quo colonial. El españolismo liberal vinculado al krausismo español también tenía sus adeptos en Cuba, básicamente entre los peninsulares, pero no exclusivamente. Nicolás Azcárate, por ejemplo, quien había nacido en Cuba pero había vivido muchos años en la metrópoli, era uno de sus defensores. Aunque mantuviera excelentes relaciones con los autonomistas, quienes anteponían su identidad cubana a sus orígenes hispánicos, Azcárate prefería la opción de la «asimilación» racional de las colonias antillanas, es decir la extensión a estos territorios de los mismos derechos y libertades disfrutados por los españoles, otorgando así a Cuba un lugar equivalente al de las otras provincias en el seno de la nación española.

La postura asimilista, heredada directamente de la voluntad liberal-krausista del Sexenio Democrático, presuponía la implantación de estas libertades en la metrópoli ${ }^{57}$. Lo cual podía haber tenido cierta validez durante el Sexenio, pero ya no la tenía en el régimen de la Restauración en el que muchas de las libertades consideradas por los krausistas como imprescindibles no estaban reconocidas y garantizadas. Por lo tanto, un autonomista como Antonio Govín admitía la posibilidad de que una colonia pudiera tener una mayor necesidad de libertad que su metrópoli, ya que «la colonia al nacer y formarse tiene ya una civilización» que «depura y engrandece», eliminando lo tradicional, los intereses creados y las preocupaciones de clase, quedándose con los principios de libertad y justicia. Esta idea se sustentaba en el ejemplo de Estados Unidos, donde Govín veía una sociedad que, por no haber conocido el Antiguo Régimen, había superado la sociedad británica en liberalismo ${ }^{58}$.

Los asimilistas representaban en 1878 una corriente poderosa en el seno del Partido Liberal cubano, hasta el punto de provocar una escisión, cuando el acto de fundación del partido estaba a punto de verificarse, que condujo a la creación del Partido Liberal Nacional. Fueron en parte convencidos y ab-

56 Sappez, 2010b: 209-210.

${ }^{57}$ Capellán de Miguel, 2005: 32.

58 "El concepto de la colonización, conferencia dada por el Dr. Antonio Govín y Torres en el Círculo Autonomista en la noche del día 14 de noviembre de 1887", Tarafa y Govín, 1955: 309-311. 
sorbidos por los autonomistas entre agosto de 1878 y el verano siguiente. Los que persistieron en su convicción asimilista intentaron organizarse en diversas ocasiones en tanto que órganos de los partidos democráticos españoles, sin éxito duradero hasta que en 1893 una fracción de la Unión Constitucional fundó el Partido Reformista ${ }^{59}$. Algunos de ellos pertenecían, en los años 1880, a logias masónicas de obediencia española que se habían implantado en Cuba, en oposición abierta con las logias de obediencia cubana, ya que negaban la soberanía de la Gran Logia Unida de Colón e Isla de Cuba, que desde 1881 agrupaba a todas las logias cubanas bajo la dirección de Antonio Govín, sobre el territorio de la isla.

Los autonomistas, por su parte, desplegaron una intensa actividad destinada a fomentar una poderosa sociedad civil que demostrara, por su calidad y por su independencia con respecto a los actores e instituciones españoles, la madurez cultural, científica y política alcanzada por el pueblo cubano. De ahí la actitud intransigente y un tanto altanera adoptada por los dirigentes masónicos cubanos, Antonio Govín antes que nadie, con respecto a los masones que prefirieran las logias de adscripción española; de ahí también, los conflictos con Rafael María de Labra originados en el empeño de los dirigentes del Partido Autonomista por no someterse al control o a los tejemanejes de ningún político o partido político español y por controlar, en todo momento, el desenvolvimiento de sus representantes en las Cortes del reino. Los autonomistas no rechazaban la herencia y las enseñanzas recibidas de la madre patria, pero solamente las asumían como algunos de los elementos a partir de los cuales se había construido la identidad cubana, un producto original en el que también integraban una importante dosis de liberalismo anglosajón. Por consiguiente, el mantenimiento del vínculo colonial con España no cumplía una función esencial de carácter nacional, sino que respondía a una coyuntura en la que una serie de circunstancias, como la composición social de la población cubana, la deriva militarista de las repúblicas hispanoamericanas y el peligro de la anexión a Estados Unidos, convertían a la autonomía en el camino más seguro hacia la implantación de un régimen liberal.

\section{CONCLUSIONES}

La estrecha conexión entre krausismo y autonomismo cubano ha pasado desapercibida por un motivo fundamental: el desconocimiento del protagonismo de Antonio Govín en la definición de la doctrina autonomista y en el

59 Roldán de Montaud, 2001: 115-143 y 517-572. Durnerin, 1979: 223-242. 
funcionamiento del Partido Autonomista en general. Como perfecto intelectual orgánico de la clase media a la que pertenecía, fue un técnico, más que un gran pensador: publicista, orador, abogado, jurisconsulto, masón, todos estos calificativos se añaden unos a otros para formar el abanico de las herramientas que usaba para participar activamente a la difusión de una cultura política específica favorable al acceso del grupo social que representaba a la hegemonía.

La historiografía cubana, que ha dedicado escasas páginas al autonomismo, ha limitado su exploración a las figuras del movimiento que resaltaron por la actividad intelectual que desempeñaron al margen de su militancia y por el papel político que tuvieron en la primera República cubana instaurada en 1902. Éste es el caso de Enrique José Varona, Eliseo Giberga y Rafael Montoro, a quien la mayor parte de los autores presentan como ideólogo incontestado y encarnación del autonomismo: no poca influencia tuvo en ello el hecho de que uno de los primeros historiadores del autonomismo, Antonio Sánchez de Bustamante y Montoro, nieto de Rafael Montoro, le atribuyera el artículo "Nuestra doctrina" (1881), en el que quedó plasmada por primera vez en detalle la doctrina autonomista, cuando fue un hecho bien conocido en la época que era Antonio Govín quien lo había redactado y defendido ante el Tribunal de Imprenta ${ }^{60}$. Los historiadores de las ideas han detectado en Montoro la impronta de Hegel, mientras que en Varona vieron la influencia de Spencer ${ }^{61}$. Con motivo de la importancia que tuvieron las llamadas corrientes positivistas en aquella época, tanto en España o en Cuba como en otras partes, y también como consecuencia del hecho de que el poco interés que la historiografía tradicional cubana fijó en el autonomismo tenía que ver con su carácter no revolucionario, el movimiento recibió rápidamente la etiqueta de «evolucionista» sin que nadie se preocupara por indagar en los orígenes de este carácter.

Se ha considerado durante mucho tiempo que el krausismo había perdido vigor en España a partir de la Restauración (1876), dejando paso al positivismo o a un «krausopositivismo» o «krausoinstitucionismo»-vinculado a la Institución Libre de Enseñanza, fundada por krausistas en 1876-. Sin embargo, los estudios más recientes sobre el tema demuestran que, en lugar de declinar, el krausismo experimentó al menos durante las dos primeras décadas de la Restauración, una importante renovación impulsada por la influencia de las tendencias asimiladas al positivismo que lo acercó a los propios orígenes

60 Sánchez de Bustamante, 1933. Montoro, 1938: 39.

${ }^{61}$ Piñera Llera, 1960: 81-96. Sobre Montoro, Sánchez de Bustamante, 1933. Martínez Bello, 1937. García Mora, 1992. Sobre Varona, Vitier, 1970: 227-248. Guadarrama y Tussel, 1987. Naranjo, 1999. 
del pensamiento de Krause. Esta filosofía, cabe recordarlo, correspondía a una visión organicista y evolucionista de la sociedad y otorgaba un lugar fundamental a las ciencias y a la razón como medio de acceder a la verdad. Orden y libertad constituían, tanto para los krausistas como para los positivistas, la vía más directa hacia el progreso. El krausismo alcanzaría, por lo tanto, «una posición de equilibrio entre positivismo e idealismo o a lo sumo un «positivismo» moderado y básicamente metodológico. En cualquier caso, su postura se decantaría hacia un lado u otro en función de la materia a considerar: en religión o moral siempre dominaría el idealismo espiritualista de corte krausiano, en las disciplinas científicas concretas a las que se dedicaban a veces profesionalmente, el influjo del positivismo se hizo sentir de forma más notoria» ${ }^{62}$.

El término «krausopositivismo» parece más apropiado para ciertos países de América Latina donde se produjo «una importante mezcla y convergencia histórica entre positivismo y krausismo» ${ }^{63}$. Tal vez pueda ser una pista para acercarnos al caso cubano. No obstante, nos parece poco probable que pudiera observarse este fenómeno, en la medida en que el krausismo de Antonio Govín y otros y sus consecuencias en cuanto al papel que le correspondía a Cuba en el escenario internacional perdió su razón de ser a partir de 1898 con la independencia de la isla y la puesta en marcha de estrechos vínculos con Estados Unidos. Los autonomistas dejaron paso a nuevos actores políticos encargados de poner en marcha una dinámica nacional. Para ello, era necesario en primer lugar olvidar las raíces españolas y romper con el eurocentrismo krausista. Por otra parte, observamos en esta nueva generación, en el plano moral, una mayor propensión a anteponer sus intereses personales al «bien común», una característica propia de las corrientes materialistas. Hombres completamente dedicados a convertir su ideal en norma de acción como eran Antonio Govín, los krausistas españoles más convencidos o el propio José Martí, en cuyo pensamiento la influencia del krausismo fue probablemente más importante de lo que parece, encontrarían difícilmente una posición cómoda, en el plano ideológico, en la República inaugurada en $1902^{64}$. Los intelectuales orgánicos del nuevo Estado serían, como indica José Antonio Piqueras, los «generales y doctores» descritos por Carlos Loveira en su famosa novela, quienes alcanzaron la hegemonía como «consecuencia de la participación en la guerra

${ }^{62}$ Capellán de Miguel, 2006: 235.

63 Ibidem: 299.

${ }^{64}$ Sobre los puntos de encuentro entre el pensamiento de José Martí y el krausismo, Serna Arnáiz, 1993: 137-145. 
de independencia y de las redes clientelares creadas durante la lucha en las regiones de procedencia» ${ }^{65}$.

Cuando los krausistas españoles habían conseguido hacer suya la Revolución de 1868, concediéndole una legitimidad excepcional con el objetivo exclusivo de implantar un sistema de self-government destinado a evolucionar por medio de reformas pacíficas, la mayor parte de los autonomistas cubanos rechazó hasta el último momento la legitimidad de la revolución en Cuba, con motivo de dos circunstancias fundamentales que no se habían dado en España: la destrucción de la economía azucarera que conllevaría una guerra y el miedo a que desencadenara un violento conflicto racial. Por otro lado, al igual que la insurrección de 1868, la revolución independentista cubana de 1895 desembocó en una larga guerra, en la cual cogió fuerza una nueva cultura política, portadora de otro sueño de armonía: el de la igualdad política y social, que no había sido el de los autonomistas. Aunque este ideal quedaría prontamente olvidado, había contribuido poderosamente a desplazar el liberalismo krausista que había predominado en las últimas décadas del siglo XIX.

\section{BiBLIOGRAFÍA}

Aguirre, Sergio, Nacionalidad y nación en el siglo XIX cubano, La Habana, Ciencias Sociales, 1990.

Alvarado Planas, Javier, Constitucionalismo y codificación en las provincias de Ultramar. La supervivencia del Antiguo Régimen en la España del XIX, Madrid, Centro de Estudios Políticos y Constitucionales, 2001.

Armas, Ramón de, Torres-Cuevas, Eduardo y Cairo Ballester, Ana, Historia de la Universidad de La Habana, 1728-1929, vol. 1, La Habana, Ciencias Sociales, 1984.

Azcárate, Gumersindo de, El self-government y la monarquía doctrinaria, Madrid, A. de San Martín, 1877.

Azcárate, Gumersindo de, El régimen parlamentario en la práctica, Madrid, Sobrinos de la Sucesora de M. Minuesa de los Ríos, 1931.

Azcárate Rosell, Rafael, Nicolás Azcárate. El reformista, La Habana, Trópico, 1939.

Bertrand, Michel y Marin, Richard (dirs.), Écrire l'histoire de l'Amérique latine. $X I X^{e}-X X^{e}$ siècles, Paris, CNRS, 2001.

Bizcarrondo, Marta y Elorza, Antonio, Cuba/España. El dilema autonomista, 18781898, Madrid, Colibrí, 2001.

${ }^{65}$ Piqueras, 2012: 425 
Capellán de Miguel, Gonzalo, Gumersindo de Azcárate. Biografía intelectual, Valladolid, Junta de Castilla y León, 2005.

Capellán de Miguel, Gonzalo, La España armónica. El proyecto del krausismo español para una sociedad en conflicto, Madrid, Biblioteca Nueva, 2006.

Castro y Bachiller, Raimundo, Don Antonio Bachiller y Morales (aspecto de su vida familiar), La Habana, Guerrero, 1942.

Catálogo de la biblioteca del Dr. Antonio Govín y Torres, donada por sus herederos a la Biblioteca de la Cámara de Representantes de la República de Cuba, La Habana, [sin ed.], 1924.

Cepero Bonilla, Raúl, “El Siglo” (1862-68). Un periódico en lucha contra la censura, La Habana, [sin ed.], 1957.

Durnerin, James, "El nacimiento del partido reformista en Cuba en 1893", Cuba, les étapes d'une libération. Hommage à Juan Marinello et Noël Salomon, Toulouse, Université de Toulouse-Le Mirail, 1979: 223-242.

García Mora, Luis Miguel, "Un cubano en la corte de la Restauración: la labor intelectual de Rafael Montoro, 1875-1878”, Revista de Indias, 195-196 (Madrid, 1992): 443-475.

García Mora, Luis Miguel, “Quiénes eran y a qué se dedicaban los autonomistas cubanos" María Teresa Cortés Zavala, Consuelo Naranjo Orovio y José Alfredo Uribe Salas (coords.), El Caribe y América Latina. El 98 en la coyuntura imperial, México, I.I.H. Universidad Michoacana de San Nicolás de Hidalgo, 1999, vol. II: 53-72.

García Mora, Luis Miguel, "La fuerza de la palabra. El autonomismo en Cuba en el último tercio del siglo XIX”, Revista de Indias, 223 (Madrid, 2001): 715-748.

García Mora, Luis Miguel y Naranjo Orovio, Consuelo, "Intelectualidad criolla y nación en Cuba, 1878-1898”, Studia Histórica. Historia Contemporánea, 15 (Salamanca, 1997): 115-134.

Gómez Treto, Raúl, "Influencia del krausismo en Cuba", El krausismo y su influencia en América Latina, Madrid, Fundación Friedrich Ebert/Instituto Fe y Secularidad, 1989: 187-209.

[Govín, Antonio], Las leyes especiales. Colección de artículos publicados en El Triunfo, órgano oficial del Partido Liberal de la Isla de Cuba, La Habana, El Cosmopolita, 1880.

Gramsci, Antonio, "La formación de los intelectuales", Manuel Sacristan (selección, traducción y notas), Antología, Madrid, Siglo XXI, 1992.

Guadarrama, Pablo y Tusell Oropeza, Edel, El pensamiento filosófico de Enrique José Varona, La Habana, Ciencias Sociales, 1987. 
Guerrero Cano, Ma Magdalena, "El contexto antillano y el Centro Hispano-Ultramarino de Cádiz”, Trocadero, 20 (Cádiz, 2008): 113-125.

La Junta Magna del Partido Liberal de Cuba, celebrada el día $1^{\circ}$ de abril de 1882 , La Habana, El Triunfo, 1882.

Lécuyer, Marie-Claude, Anticolonialisme à Cuba au XIXème siècle: Pozos Dulces (1809-1877), Paris, L'Harmattan, 2001.

López Morillas, Juan, El Krausismo español. Perfil de una aventura intelectual, Madrid, Fondo de Cultura Económica, 1980.

Martínez Bello, Antonio, "Montoro, Hegel y el Autonomismo", Revista Bimestre Cubana, 39 (La Habana, 1937): 321-346.

Martínez Gallego, Francesc A., Conservar progresando: la Unión Liberal (18561868), Valencia, Centro Francisco Tomás y Valiente UNED Alzira-Valencia/Fundación Instituto de Historia Social, 2001.

Memoria acerca del estado de la enseñanza en la Universidad de La Habana en el curso de 1868 a 1869. Anuario de 1869 a 1870, La Habana, Gobierno y Capitanía general, 1870.

Montoro, Rafael, Ideario autonomista, La Habana, Publicaciones de la Secretaría de Educación, 1938.

Morales y Morales, Vidal, Nociones de Historia de Cuba, La Habana, La Moderna Poesía, 1904.

Morales y Morales, Vidal, 3 biografías, La Habana, Ministerio de Educación, 1949.

Morales y Morales, Vidal, Hombres del 68. Rafael Morales y González, La Habana, Ciencias Sociales, 1972.

Moreno Fraginals, Manuel, Cuba/España España/Cuba. Historia común, Barcelona, Crítica, 2002.

Naranjo Orovio, Consuelo, "Evolución y revolución en el pensamiento científico de Enrique José Varona", María Teresa Cortés Zavala, Consuelo Naranjo Orovio y José Alfredo Uribe Salas, (coords.), El Caribe y América Latina. El 98 en la coyuntura imperial, México, I.I.H. Universidad Michoacana de San Nicolás de Hidalgo, 1999, vol. II: 183-202.

Naranjo Orovio, Consuelo y García González, Armando, Racismo e inmigración en Cuba en el siglo XIX, Aranjuez, Doce Calles, 1996.

Opatrný, Josef, "La formación de la imagen de la patria en la poesía e historiografía. Los casos de José Fornaris y Pedro Santacilla”, Josef Opatrný, (ed.), Nación y cultura nacional en el Caribe hispano, Praga, Universidad Carolina de Praga/ Karolinum, 2006: 45-58.

Piñera Llera, Humberto, Pensamiento de América. Panorama de la filosofía cubana, Washington D.C., Unión Panamericana, 1960. 
Piqueras, José Antonio, La Revolución democrática (1868-1874). Cuestión social, colonialismo y grupos de presión, Madrid, Ministerio de Trabajo y Seguridad, 1992.

Piqueras, José Antonio, Sociedad civil y poder en Cuba. Colonia y poscolonia, Madrid, Siglo XXI, 2005.

Piqueras, José Antonio, "Fronteras y densidad de la sociedad civil en Cuba", Imilcy Balboa (ed.), La reinvención colonial de Cuba, Santa Cruz de Tenerife, Idea, 2012: 419-468.

Piqueras, José Antonio y Sebastià, Enric, Agiotistas, negreros y partisanos. Dialéctica social en vísperas de la Revolución Gloriosa, Valencia, Alfons el Magnànim, Institució Valenciana d'Estudis i Investigació, 1991.

Rodríguez, José Ignacio, Vida del Doctor Don José Manuel Mestre, Washington D.C., W.F. Roberts Company, 1909.

Roldán de Montaud, Inés, La Restauración en Cuba: el fracaso de un proceso reformista, Madrid, CSIC, 2001.

Sánchez de Bustamante, Antonio, La ideología autonomista, La Habana, Molina y Compañía, 1933.

Sappez, Delphine, "Antonio Govín, nexo entre masonería y autonomismo en Cuba", José Antonio Ferrer Benimeli (coord.), La masonería española. Represión y exilios, Zaragoza, Gobierno de Aragón, 2010a, t. 1: 559-572.

Sappez, Delphine, "Viajar o no viajar: los autonomistas cubanos y la resistencia a abandonar el país", Josef Opatrný, (ed.), El Caribe Hispano de los siglos XIX y XX. Viajeros y testimonios, Praga, Universidad Carolina/Karolinum, 2010b: 209-218.

Sappez, Delphine, Ciudadanía y autonomismo en Cuba. Antonio Govín (1847-1914), Castellón, Universitat Jaume I, 2016.

Serna Arnáiz, Mercedes, "Algunas dilucidaciones sobre el krausismo en José Martí", Cuadernos hispanoamericanos, 521 (1993): 137-145.

Soucy, Dominique, Masonería y nación. Redes masónicas y políticas en la construcción identitaria cubana (1811-1902), Santa Cruz de Tenerife, Idea, 2006.

Stoetzer, O. Carlos, Karl Christian Friedrich Krause and his Influence in the Hispanic World, Köln/Weimar, Wien/Böhlau, 1998.

Tarafa y Govín, Josefina (ed.), Discursos de D. Antonio Govín y Torres, La Habana, Burgay y Cía, 1955.

Thiesse, Anne-Marie, La création des identités nationales. Europe XVIII ${ }^{e} X X^{e}$ siècle, Paris, Seuil, 1999.

Torres-Cuevas, Eduardo, Historia de la masonería cubana. Seis ensayos, La Habana, Imagen Contemporánea, 2005. 
Torres-Cuevas, Eduardo, Historia del pensamiento cubano, vol.1, t. II, La Habana, Ciencias Sociales, 2006.

Ureña, Enrique M., Krause, educador de la humanidad. Una biografia, Madrid, Unión/ Universidad Pontificia Comillas, 1991.

Vitier, Medardo, Las ideas y la filosofia en Cuba, La Habana, Ciencias Sociales, 1970.

Fecha de recepción: 18 de enero de 2014.

Fecha de envio de las modificaciones: 17 de junio de 2014.

Fecha de aceptación: 8 de julio de 2014.

\section{Krausism in the emergence of Cuba's nineteenth-century Reformist and Liberal Movement}

This article offers a revision of the interpretations tending to minimize the influence of Krausism in Cuba, by extending the usual field of the Cuban history of ideas to the analysis of legal and political ideas during the second half of the nineteenth century. This approach reveals the strong impact Krausism had on 1860s reformists and 1880s autonomists, and consequently on the regenerative political culture that was to affect the Cuban Republic.

Key words: Cuba; Nineteenth Century; Krausism; Reformism; Autonomism. 